\title{
PEMBERDAYAAN MASYARAKAT DALAM PENCEGAHAN PENYAKIT \\ DEMAM BERDARAH DENGUE DENGAN PENYULUHAN PERILAKU HIDUP BERSIH DAN SEHAT SERTA PEMANFAATAN BAHAN HERBAL
}

\author{
COMMUNITY EMPOWERMENT IN THE PREVENTION OF DENGUE \\ HEMORRHAGIC FEVER BY CONSELING THE BEHAVIOUR OF CLEAN AND \\ HEALTHY LIFESTYLE AND THE USE OF HERBAL INGREDIENTS
}

\author{
${ }^{1)}$ Indah Tri Susilowati, ${ }^{2}$ Endang Widhiyastuti \\ ${ }^{1)}$ Program Studi D3 Teknologi Laboratorium Medis \\ ${ }^{2)}$ Program Studi D4 Teknologi Laboratorium Medis \\ Sekolah Tinggi Ilmu Kesehatan (STIKES) Nasional \\ Jalan Solo Baki, Kwarasan, Grogol, Sukoharjo, Jawa Tengah, Indonesia. \\ Email: indahtrisusilowati@gmail.com
}

\begin{abstract}
ABSTRAK
Desa Cemani, Kecamatan Grogol, Kabupaten Sukoharjo merupakan salah satu desa yang mengalami kenaikan prevalensi Demam Berdarah Dengue (DBD), karena rendahnya pola perilaku sehat dan kurang fasilitas untuk sanitasi dan higienitas warga. Pengetahuan yang rendah mengurangi kesadaran tentang bahaya DBD. Program ini dilakukan sebagai upaya preventif DBD melalui pemanfaatan herbal menjadi produk berbasis herbal. Metode yang digunakan adalah : (1) penyuluhan tentang $D B D$, terdiri dari ciri-ciri dan penaggulangan pasien $D B D$ serta pencegahan DBD dengan menerapkan PHBS serta pemanfaatan bahan herbal, (2) Pelatihan pembuatan infus spray repellent nyamuk dengan menggunakan batang serai, dan daun cengkeh. Kegiatan ini melibatkan ibu-ibu PKK Cemani berjumlah 53 peserta. Hasil kegiatan menunjukkan ada peningkatan pengetahuan ibu-ibu PKK Cemani tentang DBD, pencegahan DBD dengan PHBS dan pemanfaatan bahan herbal sebagai spray repellent nyamuk.
\end{abstract}

Kata kunci: Demam Berdarah Dengue (DBD); Spray; Repellent Nyamuk

\begin{abstract}
Cemani Village, Grogol Subdistrict, Sukoharjo Regency is one of the villages that has experienced an increase in the prevalence of Dengue Hemorrhagic Fever, due to the low pattern of healthy behavior and lack of facilities for sanitation and hygiene of residents. Little knowledge reduces awareness about the danger of DBD. This program is carried out as a preventative measure for DBD through the use of herbs into herbal-based products. The methods used were: (1) counseling about DBD, consisting of characteristics and handling of DBD patients and prevention of DBD by applying PHBS and utilization of herbal ingredients, (2) Training in making mosquito repellent spray infusion using lemongrass stems, and clove leaves. This activity involved 53 PKI Cemani mothers. The results of the event showed that there was an increase in knowledge of Cemani PKK women about $D H F$, prevention of DHF with PHBS and the use of herbal ingredients as mosquito repellent spray.
\end{abstract}

Keywords: Dengue Hemorrhagic Fever; Spray; Mosquito Repellent 
Indah Tri Susilowati \& Endang Widhiyastuti

Pemberdayaan Masyarakat Dalam Pencegahan Penyakit Demam Berdarah Dengue Dengan Penyuluhan Perilaku Hidup Bersih dan Sehat Serta Pemanfaatan Bahan Herbal

\section{PENDAHULUAN}

Demam Berdarah Dengue banyak ditemukan di daerah tropis dan sub-tropis. Data dari seluruh dunia menunjukkan Asia menempati urutan pertama dalam jumlah penderita DBD setiap tahunnya. Sementara itu, terhitung sejak tahun 1968 hingga tahun 2009, World Health Organization $(W H O)$ mencatat Negara Indonesia sebagai Negara dengan kasus DBD tertinggi di Asia Tenggara.

Diagnosis demam berdarah dengue dapat ditegakkan berdasarkan klinis dan laboratorium. Terdapat tempa tmanifestasi klinis dari demam berdarah dengue yaitu panas tinggi, perdarahan, hepatomegaly dan kegagalan sirkulasi. Kriteria diagnosis laboratorium pada demam berdarah dengue yaitu trombositopenia $\left(100.000\right.$ sel per $\mathrm{mm}^{3}$ atau kurang), hemokonsentrasi (peningkatan hematocrit sekurangnya $20 \%$ di atas rata-rata sesuai umur, jenis kelamin dan populasi) (Kementrian Kesehatan RI, 2010).

Penyakit Demam Berdarah Dengue disebabkan oleh virus Dengue dari genus Flavivirus, family Flaviviridae. DBD ditularkan kemanusia melalui gigitan nyamuk Aedes yang terinfeksi virus Dengue. Virus Dengue penyebab Demam Dengue (DD), Demam Berdarah Dengue (DBD) dan Dengue Shock Syndrome (DSS) termasuk dalam kelompokB Arthropod Virus (Arbovirosis) yang sekarang dikenal sebagai genus Flavivirus, family Flaviviride, dan mempunyai 4 jenis serotipe, yaitu: Den-1, Den-2, Den-3, Den-4 (Kementrian Kesehatan RI, 2010).

Data Profil Kabupaten Sukoharjo 2017 dan data penderita DBD Kecamatan Grogol dari tahun 2017 ketahun 2018 kasus demam berdarah mengalami peningkatan jumlah penderita. Masih tingginya kejadian DBD khususnya Desa Cemani dapat dipengaruhi oleh faktor internal maupun eksternal seperti pengetahuan, sikap, dan perilaku masyarakat dalam memahami dan melakukan kegiatan kebersihan lingkungan rumah dalam pencegahan DBD terulang kembali.

Meningkatnya jumlah kasus serta bertambahnya wilayah yang terjangkit disebabkan karena semakin baiknya transportasi penduduk, adanya pemukiman baru, kurangnya perilaku masyarakat terhadap pembersihan sarang nyamuk, dan terdapatnya vector nyamuk hampir di semua wilayah. Faktor yang mempengaruhi kejadian penyakit demam berdarah dengue antara lain faktor host, lingkungan, perilaku hidup bersih dan sehat serta faktor virusnya sendiri. Faktor host yaitu kerentanan dan responimun; faktor lingkunganya itu kondisi geografis (ketinggian dari permukaan laut, curah hujan, angin, kelembapan, musim); kondisi demografi (kepadatan, mobilitas, perilaku, adat istiadat).

Berdasarkan wawancara dengan beberapa ibu-ibu PKK Cemani hampir sebagain besar masyarakat di desa Cemani cenderung terbiasa menggunakan obat anti nyamuk berbahan kimia yang beredar di pasaran sebagai salah satu cara untuk mengusir dan mencegah berkembangnya yamuk Aedes aegypti, landasan mereka memilih menggunakan obat anti nyamuk karena dianggap praktis, walaupun ada beberapa dari mereka mengetahui dampak negatif yang diberikan dari penggunaan obat anti nyamuk yang dipakai. Obat anti nyamuk berbahan kimia umumnya mengandung zat fumigan, DEET, Piretroid, propoksur, dan lain-lain. Kandungan tersebut sangat berbahaya karena dapat menimbulkan efek toksik baik lokal maupun sistemik terhadap manusia. Efek lokal pada umumnya melalui pajanan dermal, sedangkan efek sistemik melalui pajanan oral dan inhalasi (Raini, 2009). Dampak negatif selain merugikan kesehatan manusia juga dapat menyebabkan resistensi terhadap nyamuk itu sendiri. 
Indah Tri Susilowati \& Endang Widhiyastuti Pemberdayaan Masyarakat Dalam Pencegahan Penyakit Demam Berdarah Dengue Dengan Penyuluhan Perilaku Hidup Bersih dan Sehat Serta Pemanfaatan Bahan Herbal

Pengurangan dampak negative dengan menggunakan bahan herbal yang mampu untuk menolak gigitan nyamuk. Beberapa jenis tumbuhan ada yang dapat menghasilkan senyawa yang dapat mengganggu penyerangnya atau senyawa kimia yang bersifa tmemodifikasi perilaku serangga (repelen, antraktan) (Murad et al., 2004). Beberapa tanaman yang telah diteliti dapat dijadikan sebagai repelen karena kandungan minyak atsirinya yang mengeluarkan bau yang menyengat. Bau yang menyengat inilah yang diduga tidak disukai oleh nyamuk dan serangga lainnya.

Tanaman yang dapat digunakan sebagai penolak nyamuk adalah sereh dapur, karena minyak atsiri sereh dapur (Cymbopogon citrates (DC.) Stapf mempunyai kandungan zat aktif citronelal dan geraniol yang dapat digunakan sebagai penolak nyamuk (Gunawan, 2009). Minyak atsiri serai dapat digunakan sebagai insect repellent dengan memberikan perlindungan terhadap gigitan nyamuk sebesar 71,4 \% (Jantan \& Zaki, 1998). Tanaman kedua yang dapat berperan sebagai repellent adalah daun cengkeh, Hasil uji ekstrak daun cengkeh dosis $100 \%$ mampu menolak 93,5\% gigitan nyamuk selama 1 jam; 86,9\% selama 2 jam; 83,7\% selama 3 jam; 81,7\% selama 4 jam; 76,7\% selama 5 jam,dan $51,9 \%$ selama 6 jam. Adanya daya tolak terhadap gigitan nyamuk karena ekstrak cengkeh mengandung 70-93\% eugenol $\left(\mathrm{C}_{10} \mathrm{H}_{12} \mathrm{O}_{2}\right)$. Eugenol sudah terbukti sebagai anti jamur, antiseptik, dan anti serangga sehingga sangat cocok untuk digunakan sebagai repellent (Boesri, et all., 2015).

Berdasarkan latar belakang diatas

maka upaya pencegahan Demam

Berdarah yang digalakkan melalui kegiatan ini dilakukan dengan memberikan penyuluhan tentang Penanggulangan DBD Dengan Pelaksanaan Pola Hidup Bersih dan Sehat (PHBS) dan pembuatan spray berbahan dasar herbal berkhasiat yang telah terbukti efektif menolak nyamuk Aedes aegypti. Tujuan dari kegiatan ini adalah peningkatan pengetahuan mengenai DBD baik ciri-ciri dan penanggulangan pasien DBD dengan memanfaatkan bahan herbal berkasiat sebagai repellant nyamuk yang tumbuh disekirat pekarangan rumah warga masyarakat.

\section{METODE}

Langkah pelaksanaan untuk mencapai keberhasilan program pengabdian dengan cara :

1. Pembuatan buku pegangan mengenai tindakan preventif penyakit DBD, dengan adanya buku ini diharapkan terbentuknya kemadirian, dan kesadaran diri masyarakat dalam pencegahan DBD melalui pengenalan ciri-ciri pasien yang terkena DBD dan bagaimana tindakan awal yang harus dilakukan untuk pasien DBD, pelaksanaan PHBS (Pola Hidup Bersih dan Sehat) dengan melaksanakan 3M (menguras, menutup, menimbun dan memanfaatkan ulang), serta pemanfaatan bahan herbal berkhasiat sekitar dalam pembuatan repellent nyamuk.

2. Penyuluhan kepada Ibu-ibu PKK Cemani tentang DBD dan bagaiman acara penaggulangan pasien DBD, penerapan PHBS dalam menaggulangi DBD (diutamakan pelaksanaan 3M), serta pemanfaatan bahan herbal yang ada disekitar dalam pembuatan infusa spray repellent nyamuk.

3. Pelatihan pembuatan infusa spray repellent nyamuk dengan menggunakan batang serai, daun cengkeh dan daun jeruk purut.

Metode kegiatan pengabdian ini adalah ceramah dan tanya jawab. Ceramah dilakukan untuk mensosialisasikan informasi tentang ciri- 
Indah Tri Susilowati \& Endang Widhiyastuti

ciri serta penaggulangan bagi pasien DBD dan upaya pencegahan DBD dengan PHBS (Pelaksanaan 3M) dan pemanfaatan bahan herbal di sekitar sebagai repellent nyamuk. Selain itu metode ini dipadu dengan tanya jawab yang bertujuan sharing berbagai informasi tentang DBD, serta pencegahannya dengan PHBS dan pemanfaatan bahan herbal sebagai repellent nyamuk. Selain melalui metode ceramah juga dilakukan demonstrasi secara langsung pembutan infusa repellent nyamuk.

Pelaksanaan kegiatan pengabdian dihadiri oleh 53 peserta ibu-ibu PKK Cemani.Untuk melihat keberhasilan program pengabdian, peserta dibagikan kuesioner pretes dan posttes mengenai ciri-ciri DBD, penggulangan pasien DBD, pencegahan DBD dengan PHBS dan pemanfaatan bahan herbal sebagai repellent nyamuk.

\section{HASIL DAN PEMBAHASAN}

Pelaksanaan edukasi pada program pengabdian masyarakat ibu-ibu PKK Cemani, dilaksanakan dalam 2 tahap. Segmen pertama edukasi tentang Demam Berdarah Dengue (DBD) dan Perilaku Hidup Bersih dan Sehat (PHBS), kegiatan ini dilaksanakan untuk meningkatkan pengetahuan masyarakat terkait DBD baik ciri-ciri yang menyertai pasien DBD, penaggulangan pasien DBD dan cara pencegahan DBD melalui pelaksanaan PHBS dengan menerapkan 3M (menguras, menutup, menimbun dan memanfaatkan ulang) di lingkungan rumah tangga.

Tahap kedua edukasi tentang pemanfaatan bahan herbal yang disesuaikan dengan target untuk upaya pencegahan DBD. Dari paparan materi yang disampaikan target yang dicapai adalah pencegahan DBD dengan pembuatan bahan herbal repellent nyamuk, berdasarkan penjelasan yang telah dilakukan banyak warga yang belum mengetahui pemanfaatan bahan herbal yang mampu mengusir nyamuk dan bagaimana cara pembuatan dan penggunaanya.

Pengukuran efektifitas keberhasilan kegiatan edukasi DBD, PHBS dan Pemanfaatan Bahan Herbal dalam pencegahan DBD dilakukan dengan menggunakan pretest dan posttest. Pretest dilakukan dengan membagikan form pertanyaan untuk diisi oleh peserta sebelum dilakukan edukasi, sedangkan posttest dilakukan pada akhir sesi penyampaian program edukasi.

Form pertanyaan berisikan 13 jenis dalam bentuk multiple choice tentang DBD, PHBS dan pemanfaatan herbal berkhasiat. Dari gambaran pengujian yang telah dilakukan terdapat perubahan nilai rata-rata dari yang sebelumnya 56 pada pretest menjadi 85 pada pengujian posttest, sepeti yang disajikan pada gambar 2. Sejalan juga dengan penelitian Sugiyono (2016), adanya pengaruh pelatihan pecegahan DBD terhadap tingkat pengetahuan siswa di SDN Wirogunan 1 yaitu dari 5,49 pada saat pretest menjadi 7,89 pada saat posttest dari skor maksimal 9. Peningkatan nilai rata-rata ini menunjukkan bahwa pelatih (triner) telah berhasil dalam berkomunikasi dengan peserta pelatihan, sehingga informasi mengenai ciri-ciri serta penaggulangan bagi pasien DBD, upaya pencegahan DBD dengan PHBS (Pelaksanaan 3M) dan pemanfaatan bahan herbal di sekitar sebagai repellent nyamuk dapat tersampaikan dengan baik kepada peserta pelatihan. 


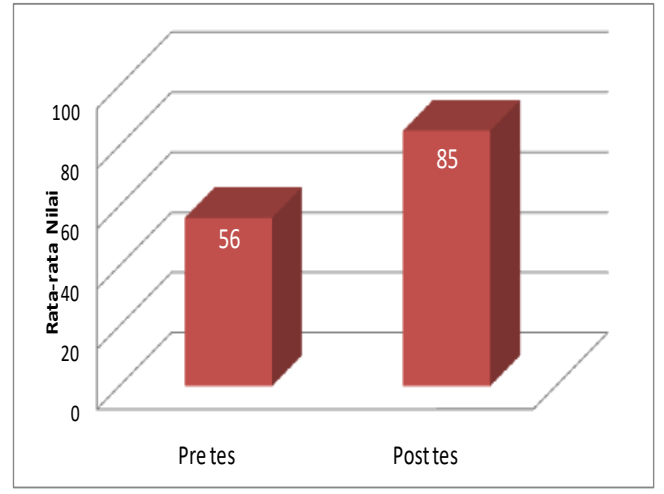

Gambar 1. Hasil Evalusi Program Edukasi.

Program pelatihan memberikan gambaran kepada masyarakat bagaimana upaya yang dapat dilakukan untuk mengembangkan bahan herbal berkhasiat yang bisa ditemukan disekitar. Pengembangan bahan herbal diwujudkan menjadi produk yang dapat diaplikasikan untuk upaya preventif DBD. Produk yang dikembangkan kepada masyarakat adalah produk yang telah didesain dalam skala laboratorium dalam prototype produk dan telah dilakukan kontrol kualitas sediaan. Beberapa bahan yang digunakan adalah: batang sere, dan daun cengkeh. Bahanbahan tersebut selanjutnya dikembangkan dalam bentuk spray.

Proses produksi pengembangan herbal berkhasiat (spray) dilakukan dalam kondisi produk setengah jadi. Dalam artian beberapa raw material disiapkan dalam bentuk siap digunakan (infusa batang serai, dan infusa daun cengkeh). Hal ini dilakukan untuk efisiensi waktu dan mempermudah dalam proses pembuatanya. Namun tetap dalam workhop warga masyarakat diberikan penjelasan secara mendetail bagaimana proses preparasi raw material yang digunakan, langkah dalam pembuatan infusa disesuaikan dengan penerapan dalam masyarakat, sehingga diharapkan ada keberlanjutan dalam pembuatan produk spray oleh masyarakat, dokumentasi dalam pembuatan produk spray ditunjukkan pada gambar 2 .
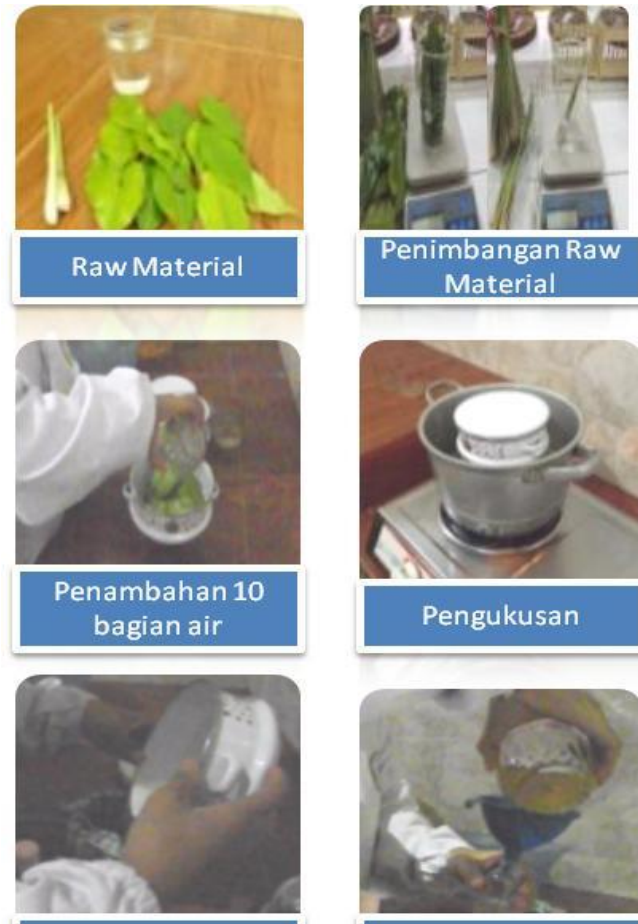
Material

Penyaringan infusa

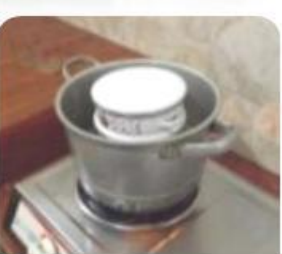

Pengukusan

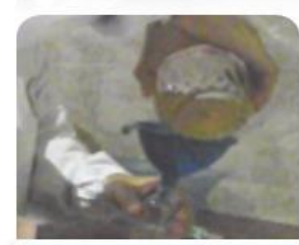

Penuangan Infusa

Gambar 2. Langkah Pembuatan sprayrepellent nyamuk.

Langkah pembuatan spray adalah dengan menyiapkan batang serai sebanyak 10 gram setara dengan 2 batang dan daun cengkeh yang tidak terlalu tua ataupun terlalu muda sebanyak 10 gram setara 12 lembar daun cengkeh, masing-masing dimasukkan dalam manci kecil ditambahkan dengan $100 \mathrm{ml}$ air atau setara dengan I gelas, manci kecil ditutup rapat dan dikukus pada air yang mendidih selama 15 menit, biarkan sampai mendingin, saring hingga diperoleh infusa, infusa yang didapat dicampur dan dimasukkan dalam botol spray untuk mengurangi aroma kuat dari daun cengkeh bisa ditambahkan daun jeruk purut. Pengunaan produk spray repellent nyamuk dengan cara menyemprotkan pada bagian tubuh yang rentan terhadap gigitan nyamuk atau disemprotkan di ruangan. Kelebihan produk spray repellent nyamuk ini adalah $100 \%$ dari 
Indah Tri Susilowati \& Endang Widhiyastuti Pemberdayaan Masyarakat Dalam Pencegahan Penyakit Demam Berdarah Dengue Dengan Penyuluhan Perilaku Hidup Bersih dan Sehat Serta Pemanfaatan Bahan Herbal

bahan alam sehingga aman bagi keluarga terutama bayi.

$$
\text { Hasil kuesioner evalusi }
$$

keterkaitan antara materi dengan aplikasi yang dapat diterapkan dimasyarakat secara langsung menunjukkan 64,15\% sangat baik yang disajikan dalam gambar 3 , ketertarikan responden terutama oleh adanya produk spray repellent nyamuk. Responden tertarik terhadap produk spray repellent nyamuk disebabkan mudah dibuat secara langsung oleh masyarakat dengan menggunakan alat yang ada dalam rumah tangga, serta pengunaan yang mudah dan aman terutama bagi bayi dan lingkungan. Hal ini sejalan dengan penelitian yang dilakukan oleh Safitri (2018), penelitian menggunakan proses ekstraksi dengan metode infudasi dikarenakan metode yang paling sederhana, juga karena kemudahan dalam proses pembuatannya, kemudahan dikarenakan tidak diperlukan bahan kimia yang berbahaya atau sulit diperoleh. Satusatunya bahan yang yang digunakan selaian bahan herbal itu sendiri adalah air, selaian itu metode dapat diterapkan secara langsung oleh masyarakat dan ramah lingkungan.

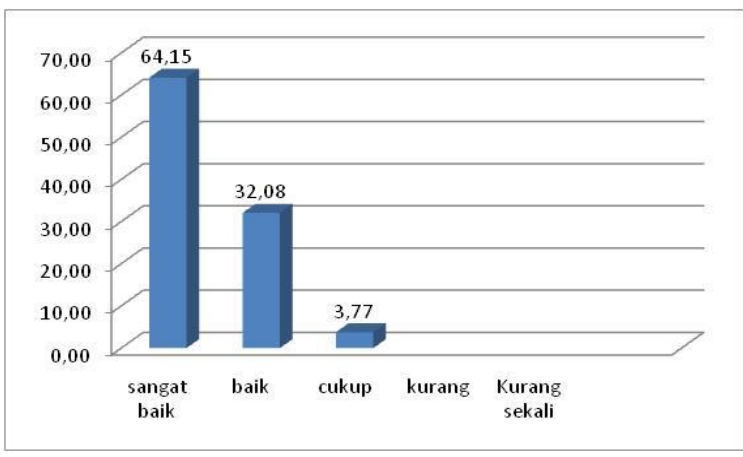

Gambar 4. Evalusi keterkaitan antara materi dengan aplikasi yang dapat diterapkan dimasyarakat secara langsung

Untuk mengetahui tingkat keberhasilan dari pelaksanaan program pengabdian masyarakat maka perlu dilakukan pemantauan maupun evaluasi.
Pemantauan dilakukan selama kegiatan hingga selesai kegiatan, dilanjutkan dengan adanya evaluasi. Evaluasi untuk program edukasi dengan mengukur tingkat pengetahuan tentang DBD, PHBS dan Pemanfaatan Bahan Herbal dalam pencegahan DBD seperti yang telah diuraikan diatas.

Pemantauan program pengabdian dengan melihat partisipasi ibu-ibu PKK Cemani yang ditunjukkan dengan adanya pertanyaan yang disampaikan.Ada 21 Pertanyaan meiputi ciri-ciri DBD, tindakan pasien DBD, PHBS, dan pemanfaatan bahan herbal sebagai repellent nyamuk. Pertanyaan mengenai pemanfaatan bahan herbal sebagai spray repellent nyamuk meliputi: 1) Keamanan penggunaan spray repellent nyamuk; 2) apakah daun cengkeh bisa diganti dengan cengkeh, 3) bagimana proses pembuatanya; 4) ketahanan dari spray repellent nyamuk yang dibuat.

\section{SIMPULAN}

Program pengabdian masyarakat yang telah dilaksanakan menunjukkan ada peningkatan pengetahuan mengenai DBD baik ciri-ciri dan penangulangan pasien DBD dengan memanfaatkan bahan herbal berkasiat yang tumbuh disekirat. Ibu-ibu PKK cemani terlibat aktif dalam program pengabdian yang ditunjukkan dengan banyakanya pertanyaan terutama dalam pembuatan produk sparay repellent nyamuk.

\section{UCAPAN TERIMA KASIH}

Penulis mengucapkan terima kasih kepada Lempaga Penelitian dan Pengabdian STIKES Nasional atas bantuan dan dukungan pelaksanaan pengabdian masyarakat yang dialksanakan pada bulan November 2018. Ucapan terima kasih juga kepada para mahasiswa (Agung, Syavira, Jessica, Anton, Prabawati, Kintan, Septiana, Daniel, Novita, dan Sekar) dari Program Studi D3 Teknologi Laboratorium Medis 
Indah Tri Susilowati \& Endang Widhiyastuti Pemberdayaan Masyarakat Dalam Pencegahan Penyakit Demam Berdarah Dengue Dengan Penyuluhan Perilaku Hidup Bersih dan Sehat Serta Pemanfaatan Bahan Herbal

atas partisipasinya pada kegiatan pengabdian masyarakat ini.

\section{DAFTAR PUSTAKA}

Boesri, H., Heriyanto, B., Susanti, L., Handayani. S.W., (2015). Uji Repelen (Daya Tolak) Beberapa Ekstrak Tumbuhan Terhadap Gigitan Nyamuk Aedes aegypti Vektor Demam Berdarah Dengue. Jurnal Vektora. 7 (2). 79-84.

Gunawan, C.N., Tjahyani, T., Soeng, S., (2009). Perbandingan Ekstrak Batang Sereh (Cymbopogon Citratus) dan Citronella Oil Sebagai Repelen terhadap Nyamuk Culex Sp Dewasa Betina. Maranatha Journal of Medicine and Health (JMH), 9 (1), $151-156$

Jantan, I., \& Zaki, Z.M., (1998). Development Of EnvironmentFriendly Insect Repellents From The Leaf Oils Of Selected Malaysian Plants. ASEAN Review of Biodiversity and Environmental Conservation (ARBEC) NovemberDecember 1999

Kementrian Kesehatan RI. (2010). Buletin Jendela Epidemiologi: Topik Pertama Demam Berdarah Dengue. Pusat Data dan Surveilans Epidemiologi. Jakarta.

Murad, S., Tjokronegoro, R. \& Sa'adah, S. (2004). Pengaruh Ekstrak dan Minyak Atsiri Rimpang Curcuma xanthorrizha ROXB., Rimpang Zingiber cassumunar ROXB., dan Bunga Nicolaia speciosa HORAN. Terhadap Nyamuk Aedes aegypti L. dalam Bionatura, Jurnal Ilmuilmu Hayati dan Fisika. 6 (1), 5367.
Raina.(2011). Ensiklopedi Tanaman Obat untuk kesehatan. Yogyakarta: Absulut.

Safitri, Isnaeni Anggi dan Cahyani, Widya Hary. (2018). Daya Bunuh Ekstrak Daun Mengkudu (Morinda citrifolia L.) dalam Bentuk Antinyamuk Cair Elektrik Terhadap Kematian Nyamuk Aedes Aegypti. Jurnal Care. 6 (1),1-14.

Sugiyono dan Darnoto, S., (2016). Pengaruh Pelatihan Pencegahan Demam Berdarah Dengue (DBD) Terhadap Tingkat Pengetahuan dan Sikap Siswa di SDN Wirogunan I Kartasura Kabupaten Sukoharjo. Jurnal Kesehatan. 9 (2). 84-92. 